\title{
Л.В. Пахаренко
}

\section{КОРЕКЦЯ ПСИХОФУНКЦІОНАЛЬНИХ ПОРУШЕНЬ У ЖІНОК З ПЕРЕДМЕНСТРУАЛЬНИМ СИНДРОМОМ}

ДВНЗ «Івано-Франківський національний медичний університет»

\begin{abstract}
Резюме. Проведено вивчення впливу диференційованого лікування на психофункціональний стан у 200 хворих на передменструальний синдром (ПМС). Встановлено, що терапія хворих ПМС має носити індивідуальний диференційований характер залежно від клінічної форми та тяжкості захворювання. Запропоноване лікування нейропсихічної та набрякової форм ПМС 3 призначенням комбінованих оральних контрацептивів, що містять дроспіренон, застосування селективних
\end{abstract}

Вступ. Передменструальний синдром (ПМС) - функціональний розлад центральної нервової системи під впливом несприятливих екзо- чи ендогенних факторів на тлі набутої або природженої лабільності гіпоталамо-гіпофізарно-оваріальної системи [1]. Взаємозв'язок психічних та нейроендокринних розладів при цій патології є очевидним та переконливо доведений багатьма дослідниками $[7,11]$. Однак ендокринні механізми є зв'язуючою та базовою ланкою. Тим не менше, хворі на ПМС мають високий рівень особистої тривожності, емоціональної лабільності, станів, пов'язаних 3 агресією, депресією або апатією, прояви яких можуть бути достатньо виражені для того, щоб зумовити значні труднощі в соціальній та професійній діяльності цих осіб [4-6]. ПМС, як біопсихосоціальний фактор, вимагає подальшого поглибленого вивчення $[8,12]$.

Враховуючи мультифакторність етіологічних та патологічних аспектів ПМС та багатогранність його клінічної картини, можна, відповідно, і нарахувати велику кількість схем лікування даної патології. Шлях до єдиного вирішення цієї проблеми ще відсутній. Необхідною $є$ корекція не тільки соматичних проявів захворювання, але й психологічних. Всі рекомендації щодо лікування ПМС можна поділити на такі групи: зміни способу життя та харчування, фармакологічна терапія та психоповедінкова терапія. Немає жодного достатньо ефективного дослідження, яке би показало перевагу одного методу терапії над іншим [9]. Патогенетично обгрунтованим є призначення гормональних препаратів, які блокують овуляцію, модуляторів нейромедіатора серотоніну $[3,10]$. Використовують також препарати, які регулюють кровопостачання, метаболізм та функціональний стан ЦНС, метаболічні, вазоактивні, нестероїдні протизапальні середники та ін. [1]. Однак на першому місці $\epsilon$ особистісний підхід до кожної пацієнтки.

Мета дослідження. Встановити вплив запропонованої диференційованої терапії на психофункціональний стан хворих на ПМС.

Матеріал і методи. Проведено обстеження 200 жінок із передменструальним синдромом, які інгібіторів зворотного захоплення серотоніну в пацієнтів 3 цефалгічною та кризовою формами та препаратів екстракту плодів прутняку звичайного в осіб із легким перебігом нейропсихічної форми ПМС сприяє більш ефективній корекції показників психофункціонального стану хворих, ніж традиційна терапія.

Ключові слова: передменструальний синдром, психофункціональний стан, лікування.

становили основну групу. Контрольну групу склали 50 практично здорових жінок без діагнозу ПМС. Верифікацію діагнозу та ступінь тяжкості захворювання (легка та тяжка форма) проводили згідно з існуючим положенням наказу № 676 MO3 України від 31.12.2004 [1]. Діагноз ПМС виставляли шляхом виявлення циклічності маніфестацій захворювання в лютеїновій фазі менструального циклу на основі збору анамнезу та ведення пацієнткою щоденника самоспостереження протягом 2-3 менструальних циклів (менструальний дистрес-опитувальник Р. Муса). Форму ПМС (набрякова, нейропсихічна, цефалгічна, кризова) визначали відповідно до класифікації В. П. Сметник [2].

Критерії включення хворих до групи спостереження: репродуктивний вік, регулярний менструальний цикл, наявність ПМС, письмова згода пацієнта. Критерії виключення: вагітність, лактація, розлади менструального циклу, вогнищева патологія молочних залоз, дисфункціональні маткові кровотечі нез'ясованої етіології, гострі запальні процеси органів малого таза, пухлини матки та яєчників невизначеної етіології, гіперпластичні процеси ендометрія, генітальний ендометріоз, тяжка соматична патологія в анамнезі, органічна патологія ЦНС, психічні захворювання, гормональні пухлини, цукровий діабет, захворювання надниркових залоз, злоякісні утвори в даний час або в анамнезі, передменструальний дисфоричний розлад, жінки, які приймали психотропні препарати або гормональну терапію на протязі останніх трьох місяців.

Психофункціональний стан жінок вивчали за допомогою тесту “Самопочуття-активністьнастрій” (САН), який вони заповнювали у другій фазі менструального циклу (22-25-й день) до лікування та через шість місяців після нього.

Всім хворим на ПМС була запропонована немедикаментозна та медикаментозна корекція порушень тривалістю шість місяців згідно з наказом MO3 України № 676. Першочергово проводилися заходи стосовно модифікації способу життя: рекомендації щодо дотримання режиму 
праці та відпочинку, помірного фізичного навантаження, сну (тривалістю до 8 год на добу), дробового режиму та певного раціону харчування. У подальшому хворі основної групи залежно від виду терапії були розподілені на дві групи - I та II. Перша група жінок отримувала запропоновану терапію, яка носила диференційований підхід. Залежно від форми та тяжкості хвороби відповідно до проведеного лікування, пацієнтки були рандомізовані на такі підгрупи:

$\mathrm{IA}_{1}$ (20 осіб) - жінки 3 нейропсихічною формою ПМС легкого ступеня, які отримували рослинний препарат на основі екстракту плодів прутняку звичайного (Agnus Castus) у дозі 40 крапель на добу; $\mathrm{IA}_{2}$ (15 осіб) - жінки 3 нейропсихічною формою тяжкого ступеня, яким призначався комбінований естроген-гестагенний препарат, що містить 20 мкг етинілестрадіолу (ЕE) та 3 мг дроспіренону в режимі 24+4; ІБ - пацієнтки 3 набряковою формою ПМС, 3 них 20 осіб з легким ступенем захворювання (IБ $)$ та 15 - 3 тяжким (ІБ $\left.\mathrm{IL}_{2}\right)$ ступенем, які приймали естроген-гестагенний препарат, що містить 30 мкг ЕЕ та 3 мг дроспіренону в режимі $21+7$; IB (18 осіб) - жінки 3 цефалгічною формою та IГ (13 пацієнток) - жінки 3 кризовою формою ПМС, які отримували селективний інгібітор зворотного захоплення серотоніну флуоксетин 20 мг на добу два дні 3 моменту настання овуляції та ще через сім днів після першого прийому препарату два дні.

Друга група жінок отримувала традиційну терапію за загальноприйнятою схемою: у другій фазі менструального циклу - вітамін Е 200 мг 1 раз на добу, вітаміни групи В (нейровітан 1 табл. 1 раз на добу), верошпірон 25 мг 2 рази на добу, свічки індометацин 0,05 г ректально 1 раз на добу. 3 метою порівняння ефективності лікування обох груп, хворі II групи були розподілені на підгрупи: IIA 1 (22 жінки) та IIA 2 (15 жінок) - особи 3 нейропсихічною формою ПМС відповідно 3 легким та тяжким перебігом; ІІБ 1 (22 жінки) та ІІБ (15 жінок) - особи з набряковою формою відповідно легкого та тяжкого ступенів; IIB (15 жінок) Хворі 3 цефалгічною та ІІГ (12 жінок) - 3 кризовою формами ПМС.

Для статистичного аналізу отриманих даних використовували програму Statistica 6.0. Вираховували середню арифметичну величину (М), стандартну похибку середнього (m), вірогідність різниць результатів дослідження (p). Для порівняння двох незалежних груп за однією ознакою застосовували непараметричний критерій МаннаУітні, для порівняння двох залежних груп - критерій Вілкоксона. Різницю між величинами, які порівнювали, вважали достовірною при $<<0,05$.

Результати дослідження та їх обговорення. За даними опитувальника САН, після шести місяців лікування значення параметрів "самопочуття”, “активність” та “настрій” зростали в I та II групах (табл.).
При легкому перебігу нейропсихічної форми як в $\mathrm{IA}_{1}$, так і в IIA 1 підгрупах, відмічено достовірне їх збільшення на тлі терапії, які досягали значень жінок контрольної групи. Проте у пацієнток $\mathrm{IA}_{1}$ підгрупи динаміка зростання показників була більш інтенсивною, ніж у IIA 1 підгрупі. Параметр “самопочуття" збільшився відповідно на 26,35 \% $(\mathrm{p}<0,001)$ та 20,44\% $\%(\mathrm{p}<0,001)$, “активність" - на $15,35 \%(p<0,001)$ та 11,35\% $(p=0,003)$, "настрій” - на 11,84\% $\%(\mathrm{p}<0,001)$ та 8,44\% $\%(\mathrm{p}=0,005)$.

Слід відмітити, що у пацієнток із тяжким перебігом запропонована терапія дала більш позитивні результати, ніж традиційна. Так, у жінок $\mathrm{IA}_{2}$ підгрупи зростання параметра “самопочуття" було на $35,99 \%(\mathrm{p}<0,003)$, у жінок IIА 2 підгрупи - на 20,95 \% ( $=0,008)$; параметра "активність" відповідно на $18,72 \%(\mathrm{p}=0,015)$ та $10,34 \%$ $(\mathrm{p}=0,013)$, “настрій” - на 20,47 \% $(\mathrm{p}=0,002)$ та $10,50 \%(\mathrm{p}=0,009)$. Проте у пацієнток $\mathrm{IA}_{2}$ підгрупи ці значення після лікування сягали показників норми, у жінок IIA 2 підгрупи - тільки показник “активність” досягав контрольної величини.

Схожа тенденція щодо динаміки показників опитувальника САН відмічена і в пацієнток із набряковою формою ПМС. Запропонована та традиційна терапія призвели практично до однакового зростання даних опитувальника в пацієн-

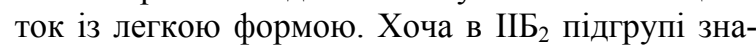
чення після лікування не були такими вираженими, як в $\mathrm{IБ}_{2}$ підгрупі, вони все таки досягали показників жінок контрольної групи. Найбільші відмінності між показниками після лікування відмічено щодо параметра “активність”, який у осіб ІБ 2 групи зріс на 30,10\% (p<0,001), а в жінок $\mathrm{IIL}_{2}$ - на $17,19 \%(\mathrm{p}=0,002)$.

На відміну від пацієнток із набряковою та нейропсихічною формами, у жінок із цефалгічною та кризовою формами ПМС нами встановлено більш виражені відмінності в результатах опитувальника САН між I та II групами після лікування. Якщо в осіб IB підгрупи параметр “самопочуття" зріс на 22,88\% (p=0,005), “активність" - на 19,66\% (p<0,001), “настрій” на $14,35 \%(p<0,001)$, то у пацієнток IIB підгрупи ми спостерігали тільки тенденцію до збільшення цих показників. У IIB підгрупі збільшення параметрів становило відповідно 8,56 \% ( $8,13 \%(\mathrm{p}=0,038)$ та 7,60\% $(\mathrm{p}=0,091)$.

Найменшу корекцію динаміки показників на тлі терапії мали жінки з кризовою формою ПМС. Запропонована терапія призвела до достовірного зростання показників, а традиційна терапія - лише до тенденції до їх збільшення. Найменші зміни констатовано при оцінці параметра “настрій”, найбільші - “самопочуття”. На тлі лікування в осіб ІГ підгрупи показник “самопочуття” збільшився на $19,46 \%$ ( $=0,003)$, IIГ підгрупи - на 11,55 \% ( $\mathrm{p}=0,033)$, параметра “активність” - відповідно на $18,01 \%(\mathrm{p}=0,004)$ та $8,89 \%(\mathrm{p}=0,005)$, “настрій" на $13,94 \%(p=0,009)$ та $6,08 \%(p=0,075)$. 


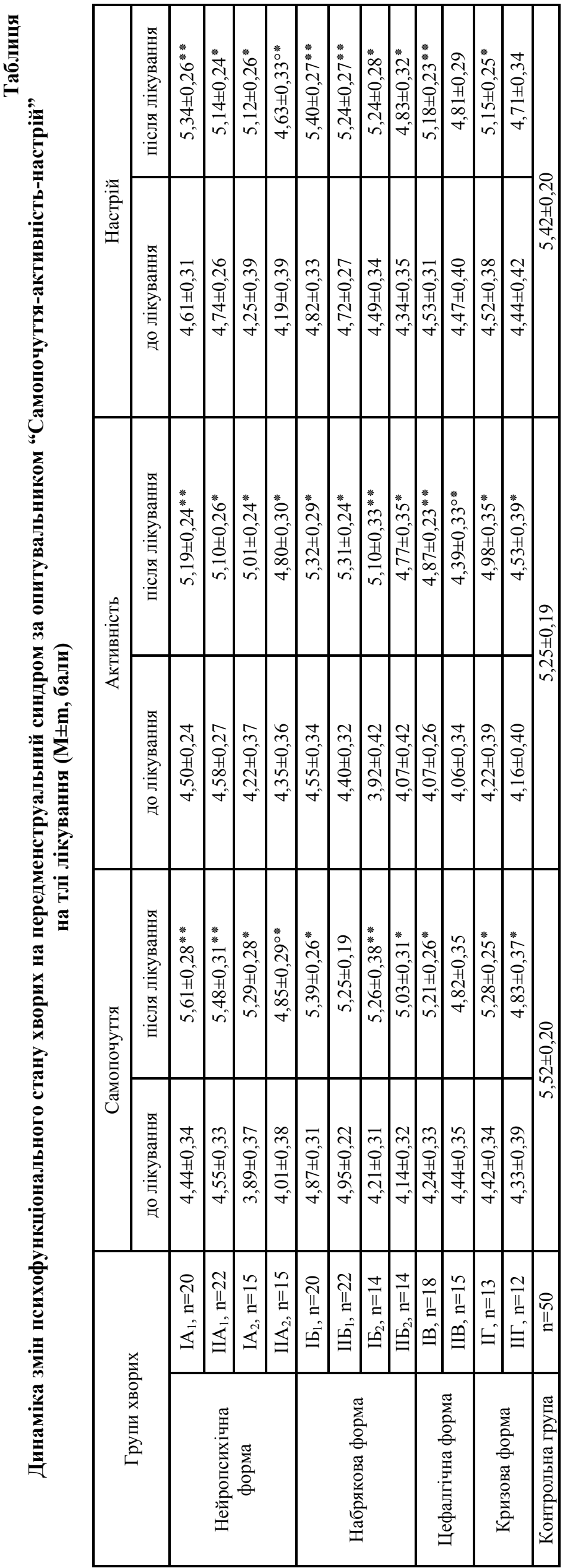

Висновки

1. Лікування хворих на передменструальний синдром має носити індивідуальний диференційований характер залежно від клінічної форми та тяжкості захворювання.

2. Традиційна терапія є достатньо ефективна для корекції психофункціональних порушень у хворих з легким перебігом нейропсихічної та набрякової форм передменструального синдрому та недостатньо результативна у цих осіб із тяжким перебігом та в осіб із цефалгічною та кризовою формами захворювання.

3. Диференційована терапія нейропсихічної та набрякової форм передменструального синдрому 3 призначенням комбінованих оральних контрацептивів, що містять дроспіренон, сприяє нормалізації рівня показників психофункціонального стану.

4. Застосування селективних інгібіторів зворотного захоплення серотоніну суттєво покращує психофункціональний стан хворих 3 цефалгічною та кризовою формами передменструального синдрому порівняно з традиційною терапією.

5. Препарати рослинного походження на основі екстракту плодів прутняку звичайного $\epsilon$ ефективними щодо корекції психофункціонального стану в жінок із легким перебігом нейропсихічної форми передменструального синдрому.

Перспективи подальших досліджень. Отримані результати спонукають оцінити вплив диференційованого підходу до лікування ПМС на інші психологічні та фізичні прояви цього захворювання.

\section{Література}

1. Наказ № 676 MO3 України від 31.12.2004 «Про затвердження клінічних протоколів з акушерської та гінекологічної допомоги».

2. Сметник В.П. Неоперативная гинекология: Руководство для врачей. Книга 1 / В.П. Сметник, Л.Г. Тумилович. СПб.: СОТИС, 1995. - С. 129-138.

3. Alba P. Premenstrual syndrome and dysphoric premenstrual syndrome / P. Alba, C. Rodríguez // Vertex. - 2014. - Vol. 25 (117). - P. 370-376.

4. Bryant C. Aspects of mental health care in the gynecological setting / C. Bryant, M. Kleinstäuber, F. Judd // Womens Health (Lond Engl). - 2014. - Vol. 10 (3). - P. 237-254

5. Clinical Profiles of Premenstrual Experiences Among Women Having Premenstrual Syndrome (PMS): Affective 
Changes Predominate and Relate to Social and Occupational Functioning / K. Schmelzer, B. Ditzen, C. Weise [et al.] // Health Care Women Int. - 2014. - Vol. 3. - P. 1-20.

6. Evaluation of Psychological Symptoms in Premenstrual Syndrome using PMR Technique / V. Jasuja, G. Purohit, S. Mendpara [et al.] // J. Clin. Diagn. Res. - 2014. Vol. 8 (4). - P. BC 1-3.

7. Indusekhar R. Psychological aspects of premenstrual syndrome / R. Indusekhar, S.B. Usman, S. O'Brien // Best Pract. Res. Clin. Obstet. Gynaecol. - 2007. - Vol. 21 (2). - P. 207-220.

8. Matsumoto T. Biopsychosocial aspects of premenstrual syndrome and premenstrual dysphoric disorder / T. Matsumoto, H. Asakura, T. Hayashi // Gynecol Endocrinol. - 2013. - Vol. 29 (1). - P. 67-73.
9. Premenstrual Syndrome and Premenstrual Dysphoric Disorder: Symptoms and Cluster Influences / F.R. PérezLópez, P. Chedraui, G. Pérez-Roncero [et al.] // The Open Psychiatry Journal. - 2009. - Vol. 3. - P. 47-57.

10. Premenstrual syndrome: management and pathophysiology / A. Imai, S. Ichigo, K. Matsunami, H. Takagi // Clin Exp Obstet Gynecol. - 2015. - Vol. 42 (2). - P. 123-128.

11. The Relationship between Severity of Premenstrual Syndrome and Psychiatric Symptoms / R. Firoozi, M. Kafi, I. Salehi, M. Shirmohammadi // Iran. J. Psychiatry. 2012. - Vol. 7 (1). - P. 36-40.

12. Ussher J.M. PMS as a process of negotiation: women's experience and management of premenstrual distress / J.M. Ussher, J. Perz // Psychol. Health. - 2013. - Vol. 28 (8). - P. 909-927.

\section{КОРРЕКЦИЯ ПСИХОФУНКЦИОНАЛЬНЫХ НАРУШЕНИЙ У ЖЕНЩИН С ПРЕДМЕНСТРУАЛЬНЫМ СИНДРОМОМ}

\section{Л.В. Пахаренко}

Резюме. Проведено изучение влияния дифференцированного лечения на психофункциональное состояние 200 больных предменструальным синдромом (ПМС). Установлено, что терапия больных ПМС должна носить индивидуальный дифференцированный характер в зависимости от клинической формы и тяжести заболевания. Предложенное лечение нейропсихической и отечной форм ПМС с применением комбинированных оральных контрацептивов, содержащих дроспиренон, использование селективных ингибиторов обратного захвата серотонина у больных с цефалгической и кризовой формами и препаратов экстракта плодов прутняка обыкновенного у лиц с легким течением нейропсихической формы ПМС способствует более эффективной коррекции показателей психофункционального состояния больных, чем традиционная терапия.

Ключевые слова: предменструальный синдром, психофункциональное состояние, лечение.

\section{CORRECTION OF PSYCHOFUNCTIONAL DISORDERS IN WOMEN WITH PREMENSTRUAL SYNDROME}

\section{L.V. Pakharenko}

Abstract. The study is devoted to assessment of the influence of differential treatment on psychofunctional state of 200 patients with premenstrual syndrome (PMS). It was found that treatment of patients with PMS should be individual and differential and depend on clinical form and severity of the disease. The proposed treatment of neuropsychical and edematous forms of PMS with combined oral contraceptives which contain drospirenone, use of selective serotonin reuptake inhibitors in patients with cephalgic and crisis forms and Vitex agnus-castus extracts in patients with mild course of neuropsychical form of PMS promotes more effective correction of psychofunctional state in patients than traditional therapy.

Key words: premenstrual syndrome, psychofunctional state, treatment.

SHEE «National Medical University» (Ivano-Frankivsk)

Рецензент - доц. С.М. Русіна

Buk. Med. Herald. - 2015. - Vol. 19, № 4 (76). - P. 137-140

Надійшла до редакції 20.07.2015 року

() Л.В. Пахаренко, 2015 